\title{
Going with the Flow: Integrated Water Resources Management, the EU Water Framework Directive and Ecological Flows
}

William Howarth, University of Kent, w.howarth@kent.ac.uk

\begin{abstract}
This paper seeks to relate broad structural themes in water regulation to the practicalities of imposing legal measures to protect aquatic ecosystems. Specifically, a contrast is drawn between the global imperative of Integrated Water Resources Management and the sectoral (issue-by-issue) approach to water regulation that has traditionally prevailed in both regional and national legislation. The intuitive attractions of 'integration' are contrasted with the challenge of interrelating the diverse purposes for which water legislation is adopted, both for human needs and for ecological purposes. These challenges are well illustrated in the European Union Water Framework Directive (WFD) which claims to adopt an 'integrated' approach, is actually concerned with water quality, largely to the exclusion of other water-related concerns. Insofar as the Directive does seek to secure integration between water quality and water quantity concerns in surface water this is only done in a secondary or incidental way. Water flow becomes relevant only where specified environmental objectives under the Directive are not being met. The legally contingent status of flow has been bolstered markedly by recent guidance under the WFD Common Implementation Strategy on Ecological Flows. The significance of this guidance is discussed and related to the implementation challenges that it raises. In relation to the UK, and particularly England, it is argued that the response to addressing water flow issues arising under the WFD had been dilatory and inadequate. Concluding observations reflect on the global, regional and national challenges for integration of water legislation as they have been illustrated by the discussion of regulating for ecological water flows.
\end{abstract}


"A river's flow is its heartbeat. Few human influences are more deadly to freshwater ecosystems than alteration of natural hydrological rhythms - the single greatest threat to our freshwater resources is the prospect that we will continue to use and manage them in the same manner as we have for the past century. Freshwater ecosystems are losing a greater proportion of their species and habitats than ecosystems on land or in the oceans. Poorly planned dams, unbalanced and unsustainable water use, and pervasive pollution have brought too many of our lakes, rivers, wetlands, aquifers, and estuaries to a tipping point."1

\section{Introduction *}

Taking a few steps back from the detail in what follows, this paper offers insights into a clash of cultures in the management and regulation of water resources.

Specifically, this concerns the degree of integration that is possible and desirable in meeting human and ecological water needs most effectively. In essence, this is a confrontation between a traditional sectoral view of water regulation and a more recent holistic view of what is required. At what level are water management and regulation best addressed?

The longstanding sectoral approach involves subjecting the different issues concerning water resources, uses and activities to separate legislation.

Characteristically, within the sectoral approach, the need for protecting the environmental quality of waters through anti-pollution laws has been addressed with surprisingly little recognition of how this relates to the legislation concerning other purposes for which water may need to be regulated. Similarly with water supply other kinds of water utility legislation, the issues are seen as essentially distinct and the regulation is largely separate and unconnected. Hence, a high degree of insulation between issue-specific water legislation may be seen as the distinctive feature of the historic sectoral approach.

Sectoralism contrasts markedly with calls for a more integrated approach to water regulation, particularly as this has advanced in recent years through the formulation and implementation of the concept of Integrated Water Resources Management (hereafter IWRM) as a primary objective for the organisational and regulation of water. In essence, IWRM is aimed at breaking down the divisions between sectoral

\footnotetext{
This paper derives from conference presentations at the World Water Congress in Edinburgh 2015 and the Society of Legal Scholars Conference in Oxford in 2016. The author is most grateful to participants at these gatherings for discussion and helpful comments. Especial gratitude is owed to Professor Maria Lee, of University College London, who offered many invaluable suggestions for improvement on an earlier draft of the paper. Any errors that remain are the work of the author alone

${ }^{1}$ The Nature Conservancy WWF Report 2010, The Implementation Challenge Taking stock of government policies to protect and restore environmental flows, T Le Quesne, E Kendy, and D Weston available at http://assets.wwf.org.uk/downloads/global flows.pdf? ga=1.63872303.1858202509.1472120256 Accessed ${ }^{* * *}$.
} 
water concerns and, to the greatest possible extent, coordinating diverse aspects of the management and regulation of water as parts of a single concern, subject to the most integrated body of legislation and administration possible. The detail of what follows, therefore, may be seen as illustrative of broader strategic debates on the extent to which traditional sectoral water legislation has been (or should be) unified in response to the requirements of IWRM.

Globally, the internationally-endorsed environmental imperative is for water management, and regulation, to progress towards IWRM. ${ }^{2}$ The implementation of this idea, however, raises many challenges because of the inevitable conflicts that arise between the diverse and often directly competing claims to water. Additionally, the challenge is intensified because of the largely un-integrated sectoral approach to water legislation that has prevailed hitherto in most jurisdictions. In both regional, and national law, water has been separately regulated for different purposes, such as securing and maintaining water supplies, pollution control, flood risk management and resource availability, alongside other matters such as hydropower, fisheries and recreational activities. In each case, the primarily utilitarian purpose behind the legislation has to be reconciled with the ecological impacts of water management and the need to respect the needs of aquatic ecosystems and biodiversity. Certainly, sectoral legal approaches have held sway in the past, with separate laws enacted for diverse water-related matters, but the increasing appreciation is that fragmented water legislation fails to reflect the realities of interconnected water uses and activities, and the vital need to connect these to ecological aspects of water resource management.

At a more practical level, the need for greater integration of water legislation in the EU seems to have been recognised for some time, but the substance of EU legislation has not matched the rhetoric. Particularly in relation to the central piece of EU water legislation, the Water Framework Directive, ${ }^{3}$ the importance of integration is fully recognised in the recitals, but only to a limited degree in the substantive content of the Directive. The WFD, it will be argued, is primarily concerned with environmental and ecological water quality to the exclusion of other, equally important, aspects of water management. Later, post WFD, measures, have sought to extend coverage to address hydrological extremes, particularly matters of flood risk planning (under the Flood Risk Management Directive ${ }^{4}$ ) and policy on

\footnotetext{
${ }^{2}$ For a useful general discussion of the concept of IWRM and it is interpretation in different jurisdictions see S. Hendry, Frameworks for Water Law Reform (2015) Ch.2.

${ }^{3}$ 2000/60/EC Directive of the European Parliament and Council of 23 October 2000 establishing a framework for Community action in the field of water policy (referred to as the 'Water Framework Directive' (WFD).

${ }^{4}$ 2007/60/EC Directive of the European Parliament and of the Council of 23 October 2007 on the assessment and management of flood risks.
} 
water shortage (under the Communication on Water Scarcity and Droughts ${ }^{5}$ ). Nonetheless, these measures appear as an afterthought to an overall sectoral state of EU law that places greatly more emphasis upon quality than quantity. Despite this, some fairly recent developments may be seen as movements towards integration in recognising the limitations of the concept of 'good status' as a central objective under the WFD. Specifically, recent attention has been directed towards the quantitative aspects of good status as an ecological requirement for surface waters. The moves to bolster the operation of the WFD in this respect are seen as an important integrative development, but perhaps only a small part of what is needed for realisation of IWRM.

Hence (to avoid raising unrealistic reader expectations) it must be stressed that this paper provides only a vignette from a much bigger canvas: depicting the wider conflict between sectoralism and integration in water legislation, ranging across the whole spectrum of human and ecological water resource management issues. The all-encompassing tussle between the big ideas in water management is narrowed down to a more manageable investigation of the legal relationship between water quality and water quantity management. Beyond that, the still narrower focus is upon how good ecological quality of surface waters is secured through measures requiring watercourses to provide a sufficient flow of water to support natural aquatic ecosystems as this is addressed in EU policy and law and, to some extent, the difficulties of translating the EU requirements into the national law of England.

Having set the discussion in its wider context, the plan of the paper is to offer some introductory observations on IWRM and the WFD to emphasise the contrasting approaches. Thereafter, the investigation seeks to ascertain to what extent the WFD adopts a genuinely holistic approach to water management and regulation. A particular focus is placed upon the treatment of water quantity management under the Directive with particular attention to the need to secure ecologically satisfactory flows of water under the environmental objectives of the Directive. As will be seen, provision for this has been generally regarded as unsatisfactory and has been the subject of a recent guidance note under the Common Implementation Strategy for the WFD. The scientific and legal challenges of ensuring good ecological status of waters is recognised and realised, and some final observations are offered as to how this might be met in practice within a particular member state, the UK and England in particular. Set against the wider backdrop, the conclusion seems to show a direction of movement towards integration, but the relatively small extent of the resulting changes serve to underline the enormity of the IWRM challenge. ${ }^{6}$

\footnotetext{
${ }^{5}$ European Commission, COM (2007) 414, and see COM (2011) 133 Third Follow Up Report to the Communication on Water Scarcity and Droughts and COM (2012) 672 Report on the Review of the European Water Scarcity and Droughts Policy and COM (2011) 13.

${ }^{6}$ See also W. Howarth, (2013) 'Integrated Water Resources Management and the Right to Water Security', FLJS Policy Brief. Oxford: Foundation for Law, Justice and Society, pp.12. Available at http://www.fljs.org/content/regulation-law-government-publications Accessed ****.
} 


\section{Integrated Water Resources Management}

Taking the broadest possible perspective, since the Rio Earth Summit Conference in 1992, the global imperative for the environment, as a whole, is to make progress towards realisation of 'sustainable development'. ${ }^{7}$ In relation to the water environment, however, the Rio Conference sets out a particular route towards sustainable development through the more specific idea of "integrated water resources management". The origins of IWRM as an imperative for the water environment are to be found in Chapter 18 of Agenda 21 from the 1992 Rio Conference. This provides that:

"the widespread scarcity, gradual destruction and aggravated pollution of freshwater resources in many world regions, along with the progressive encroachment of incompatible activities, demand integrated water resources planning and management".

Surprisingly however, IWRM was not actually defined in Agenda 21 or in any of the agreements reached at the Rio Conference and it was not until some years later that a generally accepted definition was formulated:

"IWRM is a process which promotes the co-ordinated development and management of water, land and related resources, in order to maximize the resultant economic and social welfare in an equitable manner without compromising the sustainability of vital ecosystems". ${ }^{9}$

So defined, the powerful intuitive attraction of IWRM lies in the suggestion that the aggregate of benefits (economic, social and environmental) will be at its greatest where the degree of integration of water management is highest. In reality, however, the quantification of each kind of benefit and the commensurability between these

\footnotetext{
${ }^{7}$ See the Rio Declaration on Environment and Development, available at http://www.unep.org/documents. multilingual/default.asp?documentid=78\&articleid=1163 and see A. Ross Robertson, 2012, Sustainable development law in the UK: from rhetoric to reality? Earthscan, Abingdon for a useful discussion of the national legal implications of this concept

${ }^{8}$ See United Nations, United Nations Conference on Environment \& Development Rio de Janerio, Brazil, 3 to 14 June 1992, Agenda 21 available at: http://sustainabledevelopment.un.org/content/documents/Agenda21.pdf. Accessed ${ }^{* * * *}$. See also the reaffirmation of the need for IWRM in the World Summit on Sustainable Development (2002) Plan of Implementation, Report of the World Summit on Sustainable Development, A /Conf. 199/20 p.22 available at http://www.unmillenniumproject.org/documents/131302 wssd report reissued.pdf Accessed ${ }^{* \star * *}$.

${ }^{9}$ Global Water Partnership - Technical Advisory Committee, Integrated Water Resources Management: Background Paper 4, Stockholm (2000); and see M. Rahaman and O. Varis, 'Integrated water resources management: evolution, prospects and future challenges', (2005) 1(1) Sustainability: Science, Practice, and Policy 15. For discussion of how IWRM might be applied in practice, with illustrations from different jurisdictions, see Global Water Partnership, The Handbook for Integrated Water Resources Management in Transboundary Basins of Rivers, Lakes and Aquifers (2012) http://www.gwp.org/Global/About\%20GWP/Publications/INBOGWP\%20Transboundary\%20Handbook/MGIREB-UK-2012 Web.pdf Accessed ${ }^{* * *}$.
} 
raises seemingly insuperable challenges and this has prompted some sceptical views as to the practical value of IWRM. ${ }^{10}$

It is difficult to deny that, "integration" seems to carry a highly favourable, if obscure, emotive meaning. It acquires this from its antonyms. "Integration" is the opposite of "disintegration", "disorganisation" or perhaps "chaos" (things which few people could be in favour of) and therefore it must be seen as 'a good thing'. On the other hand, "integration" begs the question, integration of what? Integration of factors A, B and $C$, might equally be seen as separating or distancing these from factors $D, E$ and $F$. What counts as 'integration' of some elements might equally be seen as involving the disintegration of others. Everything depends upon the scope of the 'integration' exercise and what it includes and excludes. ${ }^{11}$ This integration scope ambiguity may well be at work within the concept of IWRM. Although the Global Water Partnership definition, cited above, characterised IWRM as "a process which promotes the coordinated development and management of water, land and related resources" the extent of the integration process is seriously opaque. Indeed, it is difficult to conceive of any kind of environmental or natural resources management that is not in some way "related" to water management. If so, IWRM is actually turns out to be 'integrated everything management', but this is difficult to reconcile with the emphasis that seems to be placed upon the word "water". In short, the concept of IWRM gains its attraction from an explicit appeal to coherence within determinable boundaries, whilst implicitly conceding that those boundaries are elusive.

Despite these reservations about the practicality and logic of 'integration', the idea that integrated management of water is generally beneficial has an extremely broad appeal that has commanded widespread international support as the dominant global idea in water resources management. ${ }^{12}$ Notwithstanding this, its implementation involves challenges across the raft of disciplines, sub-disciplines and practices contributing to diverse water management activities, encompassing politics, economics and hydrology amongst a spectrum of natural and social science inputs. $^{13}$ Not least amongst these inputs is the vital role of law in providing an

\footnotetext{
${ }^{10}$ A widely cited critique is offered by A.K. Biswas, 'Integrated Water Resources Management: Is it working?', (2008) 24(1) Water Development Management 22. For further critical observations on IWRM see M. Giordano and T. Shan, 'From IWRM back to integrated water resources management' (2014) International Journal of Water Resources Development Vol.30 No.3 p.364. Perhaps placed at the extreme end of the sceptical spectrum, in contesting the value of IWRM as a conceptual tool, P. Jeffrey and M Gearey, 'Integrated water resources management: lost on the road from ambition to realisation' (2006) Water Science \& Technology Vol.53 No.1 p.1

${ }_{11}^{1}$ J. G. Hering and K. M. Ingold, 'Water Resources Management: What Should be Integrated?' (2012) 8 June 2012 Vol.336 Science (published by the American Association for the Advancement of Science). Further on the definitional confusion as to the precise meaning of IWRM see N. S. Grigg, 'Integrated water resources management: balancing views and improving practice' (2008) Water International Vol.33 No.3 p.279.

${ }_{12}$ UN Water Report, The Status Report on the Application of Integrated Approaches to Water Resources Management (UN, 2012) and see the United Nations, International Decade for Action, Water For Life 2005-2015 web pages at http://www.un.org/waterforlifedecade/iwrm.shtml Accessed $\star * \star *$.

${ }^{13}$ For an interdisciplinary discussion of the foundational principles of integrated governance of water, particularly in respect of water, shortage and flood risk, see M. van Risjswick, J. Edelenbosb, P.
} 
institutional and normative framework to support other water management activities. Accordingly, viewed from a legal perspective, the greatest conformity with IWRM might be achieved where there is the maximum degree of coordination between laws and administrative requirements relating to all aspects of water management. Possibly, this might be seen as the state of affairs where all matters related to water are provided for under a single codifying statute and where legal powers and duties under that statute are exercised by the minimum number of different regulatory bodies or made subject to the least possible number of administrative boundaries. In the real world, however, actual water management law and administration seems, invariably, to fall some way short of this comprehensively unified ideal. ${ }^{14}$

It is tentatively suggested that the reasons for the limited progress towards IWRM as a legislative goal are attributable to the formidable challenge of reconciling and coordinating the range of purposes for which water-regulation may be adopted. Traditionally, the common purpose of water regulation has tended to be utilitarian, in the sense of protecting a range of recognised water uses to secure human benefit. Progressively however, the 'intrinsic value' of the water environment and the ecosystems and species that it supports has been taken as a basis for legislation, even where this may not be justified on strict utilitarian grounds. Even within the utilitarian branch of water legislation, contrasts may be drawn between regulation of consumptive and non-consumptive water uses, according to the extent to which water is returned to the source of supply after use. In reality, 'consumptive' is a matter of degree, measuring the proportion of water returned and perhaps the alteration in the quality of water that as returned, as where water is contaminated or heated. Nonetheless, use of water for agricultural irrigation and for some industrial processes might be placed at the 'more consumptive' end of the spectrum, followed by water used for drinking and domestic purposes, and water used for dispersal of waste as in sewage or effluent treatment activities. 'Less consumptive' or nonconsumptive uses of water might be illustrated by uses in generating hydropower, in navigation, in supporting fisheries and enabling recreational water use. This list is far from being exhaustive of all the possible water uses, but serves to show the range and diversity of activities that water legislation may be seeking to address.

The main point to be drawn from outlining the range of possible water uses is that different users may be best seen as competitors for a finite natural resource, where allocation of water to one group of users may be seen, to varying degrees, as excluding others. As between the different uses, the potential for incompatibility is markedly variable, with consumptive uses necessarily reducing water availability for

Hellegersc, M. Kokd and S. Kuks, 'Ten building blocks for sustainable water governance: an integrated method to assess the governance of water' (2014) Water International Vol.39 No.5 p.725.

${ }^{14}$ See for example the UK Government's Legislation.gov.uk website of statutory information where a search of primary legislation on "water" produces 47 hits concerning a wide spectrum of water regulatory issues across the different jurisdictions within the UK. Notably, this does not encompass various water-related matters where "water" does not appear in the title of the statute, such as fisheries legislation, for example. Accessed ${ }^{* * * * *}$ 
other less or non-consumptive uses. The element of competition between uses is almost invariably present. Hence, a key element in water management may be seen as allocating priorities between competing water uses. The proposal that water management should be 'integrated' may be seen as shedding unhelpfully little light upon how this exercise should be undertaken.

\section{Integration and the Water Framework Directive}

Integration and environmental law are close relations. Indeed, a large part of the modern environmental quality law of England may fairly be seen as the product of an integration process that has brought together separate pollution control laws, concerned with air, water and waste. These have been progressively subjected to unified systems of regulation such as 'integrated pollution control' 15 and harmonised 'environmental permitting' requirements. ${ }^{16}$ This is not to say that environmental law is now fully integrated (far from it) but integration must at least be seen as a major theme in the evolution of national environmental law over the last quarter century or more. Similarly at EU level, the markedly sectoral measures adopted as the first inroads of the European Economic Community into environmental legislation has progressively been overtaken by more harmonised and coordinated approaches to environmental quality legislation. ${ }^{17}$ The remarkable contrast, from the present perspective, is that the integration of environmental law has not been paralleled by any significant degree of integration of water law, though some movement in that direction may be discerned in the following discussion.

As a general matter, integration (in a different sense) is a long-recognised goal of EU environmental law, with this objective now affirmed by Article 11 of the Treaty on the Functioning of the European Union which provides for the integration of environmental protection requirements across Union policies and activities. ${ }^{18}$ This might be taken to encompass the linking of water management with Union environmental policy principles, of precaution, prevention and making polluters pay, ${ }^{19}$ and the application of environmental protection requirements to non-environmental sectors of Union activity which might adversely impact upon water management.

\footnotetext{
${ }^{15}$ See Part I of Environmental Protection Act 1990 on Integrated Pollution Control.

${ }^{16}$ See Environmental Permitting (England and Wales) Regulations 2010 (SI 2010/675).

${ }^{17}$ See Directive 96/61/EC on Integrated Pollution Prevention and Directive 2010/75/EU on Industrial Emissions.

${ }^{18}$ See the extensive survey by N. Dhondt, Integration of Environmental Protection into other EC Policies (Europa Law Publishing, 2003) though contrast J. Hertin and F. Berkhout, 'Analysing Institutional Strategies for Environmental Policy Integration: The case of EU Enterprise Policy' (2003) Journal of Environmental Policy \& Planning Vol.5(1) p.39, suggesting that there is an antagonistic relationship between industry and the environment, and the impact of environmental policy implementation has been modest because non-environmental policy sectors have found ways to reduce environmental interventions which they see as a threat to their interests.

${ }^{19}$ Art.191(2) Treaty on the Functioning of the European Union and see M. Lee, EU Environmental Law, Governance and Decision-Making, $2^{\text {nd }}$ ed. (2014) Ch. 1 for a useful discussion of the EU Environmental Policy Principles and R. Macrory, ed., Principles of European Environmental Law (2004).
} 
However, the furtherance of 'integration', in this sense, has been generally limited, perhaps showing a disconnect between policy and practice, involving a continual reopening of debate about the normative meaning of 'integration'. ${ }^{20}$ For whatever reason, there seems to show relatively little progress in linking water management to other related areas of EU activity, such as the EU's Common Agricultural Policy, which has profound implications for the state of the water environment. ${ }^{21}$

Within the body EU legislation concerned specifically with water, the degree of 'integration', in the sense of adopting an IWRM approach, is also very limited. The key Directive concerned with the aquatic environment, the WFD, may have claimed to have provided for integration in the protection and sustainable management of waters but, in reality, the basis for this claim is relatively limited. Notably, the WFD falls some way short of a comprehensive codification of EU water legislation, with important water Directives, concerning Drinking Water Quality (98/83/EC), Bathing Water Quality (75/160/EEC and 2006/7/EC) Municipal Waste Water Treatment (91/271/EEC) and Agricultural Nitrates (91/676/EEC) remaining largely separate from the WFD. Even within its own boundaries, the WFD lacks an interface with other policies and legislation which have significant implications for the aquatic environment and wider issues of water management. In short, the WFD pays little regard to matters of water quantity and the raft of other water management issues that fall within the scope of IWRM.

There is no shortage of integration rhetoric in the WFD, but this is not matched by substance. ${ }^{22}$ As pronounced in the preamble, the Directive furthers the development of an integrated EU policy on water, the integration of protection and sustainable management of waters, and the integration of water with other EU policy areas. ${ }^{23}$ However, the content of the Directive falls some way short of the holistic approach that might be expected. Hence, the stated main purposes of the Directive are to establish a framework for the 'protection' (rather than the 'management') of all relevant inland surface waters, transitional waters, coastal waters and groundwaters which: (a) prevents further deterioration; (b) promotes sustainable water use; (c) aims at enhanced protection and improvement of the aquatic environment; (d) ensures progressive reduction of pollution of groundwater; and (e) contributes to

\footnotetext{
${ }^{20}$ A. Jordan and A. Lenschow, 'Environmental Policy Integration: a State of the Art Review' (2010) 20 Environmental Policy and Governance 147 and C. Adelle, A. Jordan and J. Turnpenny, 'Policy Making' Ch.13 p.209 in Environmental Policy in the EU : Actors, Institutions and Processes ( $3^{\text {rd }}$ ed. Earthscan 2013).

${ }^{21}$ See W. Howarth, 'Integrated Water Resources Management and the European Union Common Agricultural Policy', in Research Handbook on EU Agriculture Law, eds. M. Cardwell and J. McMahon 2016 Edward Elgar

${ }^{22}$ For a pertinent discussion of the disparities between the WFD and IWRM and other international commitments with regard to water management see M. M. Rahman, O. Varis and T. Kajander, 'EU Water Framework Directive vs. Integrated Water Resources Management: The Seven Mismatches' (2004) Water Resources Development Vol.20 No.4 p.565.

${ }^{23}$ WFD, 2000/60/EC, Recitals 9, 16 and 18.
} 
mitigating the effects of floods and droughts. ${ }^{24}$ Of these five objectives, it is notable that the second seems to be limited to limited to cost-recovery pricing for the provision of water services ${ }^{25}$ and only the last seems to be particularly relevant to quantitative water resources management. Moreover, there is only limited coverage of the relationship between water quality, or quantity, and the range of different water uses that have been previously noted.

\section{Quantitative Water Management under the WFD}

Skipping much technical detail on the WFD, ${ }^{26}$ the essence of the regime that is provided for is that river catchment areas are taken as the geographical unit for administrative application of the Directive. Hence, member states are to designate River Basin Districts, or facilitate the designation of International River Basin Districts, for which River Basin Management Plans (RBMPs) are established by the competent authorities. After monitoring and making appropriate assessments of waters ${ }^{27}$ appropriate administrative measures are to be put in place to enable coordinated programmes of measures (PoMs) to be implemented at river basin district level to enable the environmental objectives of the Directive to be realised. ${ }^{28}$ Notably, for the purpose of the discussion that follows, the basic measures in a PoM are to include controls over the abstraction of surface water and groundwater. In addition, measures should be considered to ensure that the hydromorphological conditions of bodies of water are consistent with the achievement of the required ecological status for the waters. ${ }^{29}$

Taken down to its bare bones, the WFD involves putting in place timely measures to meet the environmental objectives of the Directive to protect and, where necessary, restore the structure and function of aquatic ecosystems and safeguard the sustainable use of water resources. The essence of this is that the principal environmental objectives for surface waters impose requirements to: (1) prevent deterioration in status; (2) protect, enhance and restore waters with the aim of achieving good status; (3) protect and enhance, all artificial and heavily modified waters with the aim of achieving good ecological potential and food surface water chemical status; and (4) implement measures necessary for reducing pollution from

\footnotetext{
${ }^{24}$ Art. 1 WFD

${ }^{25}$ Art 9 WFD and cite literature sources H. Unnerstall, The Principle of Full Cost Recovery in the EUWater Framework Directive - Genesis and Content (2007) Journal of Environmental Law Vol.19 No.1 p.29 and W. Howarth, 'Cost Recovery for Water Services and the Polluter Pays Principle' [2009] ERA Forum (the Journal of the Academy of European Law) pp.1 to 23 (DOI 10.1007/s12027-009-0134-3).

${ }^{26}$ For a more detailed account see W. Howarth and D. McGillivray, Water Pollution and Water Quality Law (2001) ss.5.7-10 and D. Grimeaud, 'Reforming EU water law: towards sustainability' [2001] European Environmental Law Review 41 to 51, 88 to 97 and 125 to 135.

${ }^{27}$ See Art.8 WFD on Monitoring of surface water status, groundwater status and protected areas, and see Art 5 WFD on Characteristics of the river basin district, review of the environmental impact of human activity and economic analysis of water use.

${ }^{28}$ See Art.11 WFD on Programmes of Measures.

${ }^{29}$ Art.11(3)(e) and (i) WFD.
} 
priority substances and taking actions in relation to priority hazardous substances. ${ }^{30}$ Distinct environmental objectives are provided for in relation to groundwater and

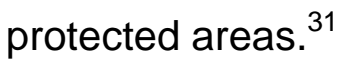

In respect of surface waters therefore, a key aspect of realising the environmental objectives under the WFD is the achievement of the good status objective, though the quantitative aspects of this are not readily apparent. For surface waters, 'good status' means the combination of 'good ecological status' and 'good chemical status'. ${ }^{32}$ In most respects this means that waters will support the kind of species and ecosystem that are appropriate, given the characterisation of the water, and that the presence of chemical and other pollutants does not exceed relevant environmental quality parameters. Further detail is provided by Annex $\mathrm{V}$ to the Directive, concerned with the quality of surface waters, which indicates that good ecological status for rivers also encompasses certain hydromorphological features, concerning the hydrological (flow) regime, river continuity and morphological (shape) conditions. However, in each case, the 'good status' classification requires only that these parameters should be 'consistent with the achievement of the values specified ... for the biological quality elements'. ${ }^{33}$ One reading of this is that river water flows should not be so far from their natural state that the biological aspects of good ecological status cannot be realised. If so, watercourse flow only becomes an issue when it can be identified as a reason for a river to fail to meet good ecological status. The inference to be drawn from this is that quantitative status for surface water quality is not an expressly stated requirement for good surface water status, but it may become significant in circumstances where unsatisfactory flow is found to be a reason for a failure of a watercourse to meet good ecological status. In that sense, water flow may be seen as a 'secondary', 'incidental' or 'contingent' ecological requirement for good status of surface waters under the WFD. The wider significance of this will be returned to later.

\section{Qualifications and Exceptions on Quantitative Good Status}

Whilst characterising surface water flow as a 'contingent' aspect of ecological good status serves to set the stage for later discussion, this statement is misleading or simply incorrect without noting those respects in which water quantity is otherwise provided for under the WFD. On this, four matters need brief consideration: high status waters, exceptions from the good status requirement, groundwater and protected areas.

\section{A High Status Waters}

\footnotetext{
${ }^{30}$ Art.4(1)(a) WFD.

${ }^{31}$ Art.4(1)(b) and (c) WFD.

${ }^{32}$ Art.2(18) WFD.

${ }^{33}$ Annex V Table 1.2 WFD.
} 
The general water classification scheme under Annex $V$ to the WFD requires water bodies to be assessed and assigned to one of five status classes: high, good, moderate, poor or bad. The criteria differ according to the category of water concerned, but for surface waters the quality elements that must be used for the assessment of ecological status of surface waters (rivers, lakes, transitional waters or coastal waters) are biological, hydromorphological and physico-chemical. In respect of the 'high ecological status' classification for surface waters the relevant hydrological requirement is that "the quantity and dynamics of flow, and the resultant connection to groundwaters, reflect totally, or nearly totally, undisturbed conditions". ${ }^{34}$ In effect, the water flow required for high ecological status classification is that of minimal anthropogenic alteration, as compared to the natural state of the water. This contrasts with requirements for good or moderate status where the hydromorphological elements require only "conditions consistent with the achievement of the values specified for the biological quality elements". ${ }^{35}$ That is, the water flow regime for good status, for example, allows biological quality elements (concerned with phytoplankton, macrophytes and phytobenthos, benthic invertebrate fauna, and fish fauna) to show only slight changes in composition and abundance as compared to undisturbed conditions. In effect, an explicit and fairly precise water flow requirement is specified for high status surface waters: undisturbed conditions. This contrasts with the relatively unspecific requirements for good status waters, which allow "slight" change consistent with the achievement of the biological quality elements.

\section{B Exceptions from the Good Status Requirement}

Despite the common preconception that the WFD is all about securing good status for relevant waters, the reality is that quite a large proportion of waters fall outside the good status requirement. Specifically, provision is made for waters to classified as Artificial Water Bodies (AWB) or Heavily Modified Water Bodies (HMWB) where construction or substantial physical changes in hydromorphological conditions have the consequence that good status cannot be achieved without significant adverse effects upon the wider environment and/or a range of human water uses. ${ }^{36}$ In respect of these waters the relevant environmental objective is that of good ecological potentia $\left.\right|^{37}$ which is intended to reflect, as closely as possible, the biological conditions associated with the nearest comparable natural water body. ${ }^{38}$

\footnotetext{
${ }^{34}$ Annex V para.1.2 table 1.2 WFD.

35 Ibid.

${ }^{36}$ Article 4(3)(a)) WFD. Article 2(9) of the WFD, "a heavily modified water body means a body of surface water which as a result of physical alterations by human activity is substantially changed in character".

${ }^{37}$ Art 1(A)(iii) WFD.

${ }^{38}$ see WFD CIS, Guidance document No.4 Identification and Designation of Heavily Modified and Artificial Water Bodies (2003) Section 6.2.3 available at https://circabc.europa.eu/sd/a/f9b057f4-4a9146a3-b69a-e23b4cada8ef/Guidance\%20No\%204\%20-

\%20heavily\%20modified\%20water\%20bodies\%20-\%20HMWB\%20(WG\%202.2).pdf Accessed ****.
} 
Environmental standards below good status may also be required in circumstances where a derogation or waiver is provided for under the Directive. Hence, the time limit for achievement of good status can be extended if achieving good status would be disproportionately expensive or the magnitude of improvement needed is only achievable in a longer timeframe for reasons of technical feasibility or because the natural conditions do not allow timely improvement in the status of the water body. ${ }^{39}$ Less stringent environmental objectives may be set if a water body is so affected by human activity or its natural condition is such that achieving 'good' status would be unfeasible or disproportionately expensive and the environmental and socioeconomic needs served by the human activity cannot be achieved by other means which are a better environmental option and not entailing disproportionate costs. ${ }^{40}$ Another possibility is that a temporary derogation can be granted if the water body is affected by an exceptional natural cause or force majeure which could not reasonable have been foreseen. ${ }^{41}$ In each case, specific conditions must be met for the derogation to be granted, no further deterioration can occur in the status of the affected body and the use of the derogation, and the reasons for it, must be specifically set out and explained in the relevant river basin management plan. ${ }^{42}$ The upshot of all this is that there is quite a wide facility for surface waters to become subject to requirements that are less strict than good status, but should nonetheless meet hydromorphological criteria, including flow, that are as close as the circumstances permit to those required for good status.

\section{Groundwater}

The third exception to the general WFD water flow requirements concerns the status of groundwater, which is determined by the poorer of its quantitative and its chemical status. ${ }^{43}$ 'Quantitative status' here relates to the extent to which a body of groundwater is affected by direct and indirect abstractions. ${ }^{44}$ Alongside qualitative concerns, the Directive requires a balance to be drawn between abstraction and recharge of groundwater, subject to similar exceptions and qualifications as apply in relation to the good status requirement for surface waters. ${ }^{45}$ The notable contrast here is that groundwater is subject to an explicit quantitative requirement for good status, which does not apply to surface waters. The level of water in a groundwater body must be such that the available groundwater resource is not exceeded by the long-term annual average rate of abstraction. ${ }^{46}$ Accordingly, the level of groundwater should not be subject to anthropogenic alteration such as would result in: failure to achieve the environmental objectives for groundwater; any significant

\footnotetext{
${ }^{39}$ Art.4(4) WFD.

${ }^{40}$ Art.4(5) WFD.

${ }^{41}$ Art.4(6) WFD.

${ }^{42}$ Art.4(7) WFD

${ }^{43}$ Art.2(1) WFD.

${ }^{44}$ Art.2(26) WFD.

${ }^{45}$ Art.4(1)(b) WFD.

${ }^{46}$ Annex V 2.1.2 WFD.
} 
diminution of status; and any significant damage to terrestrial ecosystems that depend directly on the groundwater body; and there are no saline or other intrusions resulting from anthropogenically induced sustained changes in flow direction. ${ }^{47}$ The reason why groundwater should be subject to this explicit quantitative status requirement ,which is denied to surface waters, is not apparent and the common interdependence between surface and groundwater flow makes the difference in treatment particularly difficult to rationalise.

\section{$D$ Protected Areas}

A final departure from the good status quantitative requirements arises in relation to distinct environmental objectives that may be set for protected areas under the WFD. ${ }^{48}$ Notably, where waters have environmental objectives for surface waters alongside further objectives arising from designation as a protected area, the most stringent set of objectives should be applied. ${ }^{49}$ So the general good status requirement for surface waters may be displaced by a more stringent objective where the water falls within an area that is protected for various reasons. ${ }^{50}$ In respect of this, the Directive requires a register of protected areas to be established encompassing waters for a range of purposes, including water for human consumption, economically significant aquatic species, bathing waters, nutrientsensitive areas and areas of the protection of habitats or species where maintenance or improvement of the status of water is an important factor in their protection, including relevant Natura 2000 sites designated under the Habitats and Birds Directives. ${ }^{51}$

Perhaps most pertinently to the present discussion, the EU Habitats Directive requires measures to be taken in Natura 2000 sites to maintain or to restore, at a favourable conservation status, natural habitats and species of wild fauna and flora of EU interest. ${ }^{52}$ The Directive specifies that the necessary conservation measures must correspond to the ecological requirements of specified natural habitat types and the species present on the sites. ${ }^{53}$ No definition is provided of the 'ecological requirements', but it would be reasonable to conclude that these would include their relations with the aquatic environment in respect of water flow. ${ }^{54}$ Hence, these flows

\footnotetext{
${ }^{47}$ See CIS, Guidance Document No. 18 Guidance on Groundwater Status and Trend Assessment (2009) and European Environment Agency, Report 11/2012 Water Resources in Europe in the Context of Vulnerability (2012) p.36 available at http://www.eea.europa.eu/publications/waterresources-and-vulnerability Accessed ${ }^{* * *}$.

${ }^{48}$ Art.4(1)(c) WFD.

${ }^{49}$ Art.4(2) WFD.

${ }^{50}$ Under Art.6 and Annex IV WFD.

${ }^{51}$ 92/43/EEC and 79/409/EEC (now 2009/147/EC) Annex IV WFD

${ }^{52}$ Art.2(2) Habitats Directive.

${ }^{53}$ Art.6(1) Habitats Directive.

${ }^{54}$ European Commission, Managing Natura 2000 Sites: The Provisions of Article 6 of the Habitats Directive, 2000 available at
} 
must be maintained at levels determined by the ecological requirements of protected habitats or species and these will override any water flow requirements arising under the WFD.

\section{E The General Position on Water Flow under the WFD}

Having briefly summarised the four exceptions, the general position on water flow requirements under the WFD may now be revisited. The WFD does not impose any explicit quantitative requirement for water flows in the achievement of good status for surface waters. The only requirement is that flow is 'consistent with the achievement of the values specified for the biological quality elements' under the Directive. Hence, flow may be regarded as 'contingently' relevant to good status in the sense that it becomes applicable only where human alteration of the natural flow prevents the achievement of biological elements of good status. Where this is found to happen is far from clear given the uncertain scientific relationship between the flow and ecological state of any particular water.

It is remarkable that the WFD does not specify any particular flow regime that is needed to achieve the good status of surface waters in more explicit terms. The implication is that good ecological status is unlikely to be achieved in a water body with significantly altered flows, however, the interrelationship between natural flow and ecological quality is far from being an a priori truth. As a matter of environmental science the possibility remains that a water might be ecologically satisfactory despite an unsatisfactory flow or, conversely, it might be ecologically unsatisfactory despite a natural flow, as where there are other factors having an adverse ecological impact. Given the lack of correlativity involved, a significant degree of discretion will be open to member states in deciding what departures from natural flows will be permitted on the basis that they will not impair the achievement of good ecological status. ${ }^{55}$ Not surprisingly, the lack of specific provision for water flow under the Directive has attracted much criticism.

\section{The Critique of Flow Provision under WFD and the EU Blueprint}

In 2012, the European Year of Water ${ }^{56}$ the European Commission undertook a major review of water policy, culminating in the publication of $A$ Blueprint to

\footnotetext{
http://ec.europa.eu/environment/nature/natura2000/management/docs/art6/provision of art6 en.pdf Accessed ${ }^{* * * *}$.

${ }^{55}$ See, for example, the WFD 48 Project involved a panel of ecologists sought to ascertain acceptable flow parameters and key components of the biota across the range of UK Rivers. The project produced lookup tables for each river type, specifying the maximum abstraction allowable at different flows. (reported by Acreman, M.C., M.J. Dunbar, J. Hannaford, A. Black, O. Bragg, J. Rowan, and J. King. 2005. Development of environmental standards (Water Resources). Stage 3: Environmental Standards for the Water Framework Directive. Report to the Scotland and Northern Ireland Forum for Environment Research. Wallingford and Dundee: Centre for Ecology and Hydrology and University of Dundee)

${ }^{56}$ For details see http://www.eea.europa.eu/themes/water/water-assessments-2012.
} 
Safeguard Europe's Water Resources. ${ }^{57}$ The Blueprint and a range of investigations and studies which fed into its preparation provided a useful evaluation of the operation of the WFD after its first decade of implementation, and served to highlight its strategic shortcomings. ${ }^{58}$ As the first subheading of the Report put it: "Rationale for the Blueprint: the Status of EU Waters is Not Doing Well Enough!" Indeed, findings reported by the European Environment Agency had shown that, despite national actions to implement the Directive, the ecological status of many of Europe's waters remained disturbingly poor.

"More than half of the surface water bodies in Europe are reported to be in less than good ecological status or potential, and will need mitigation and/or restoration measures to meet the Water Framework Directive objective. By $2015,52 \%$ of water bodies are expected to reach good status, compared with $42 \%$ in 2009. This falls well short of the objective, with only a modest improvement expected between 2009 and 2015. ${ }^{59}$

The UK House of Lords Report, An Indispensable Resource ${ }^{60}$ offered some telling observations on the reasons for this unsatisfactory state of affairs. Although characterising the WFD as 'a force for good' in adopting a holistic approach and a sound level of ambition, attention was drawn to its methodological shortcomings. Specifically, it was suggested that Directive's aim of 'good status' for all water bodies could not be effectively pursued without action on water resource availability. Greater attention needed to be drawn to the critical dependencies between water and its availability and the need to encourage national water scarcity and drought management plans. ${ }^{61}$ The Report noted,

"In practice, the distinction [between quality and availability of water resources] can be non-existent... . There is a need to bring policy development on the two strands closer together. The [European] Commission told us that the Commission's "fitness check" had shown that quantitative water management was one of the issues that had not been particularly well covered by the Water Framework Directive. We ... . consider that the 'good

\footnotetext{
${ }^{57}$ The EU Blueprint: European Commission COM(2012) 673 final, A Blueprint to Safeguard Europe's Water Resources (2012).

${ }^{58}$ Contrast Commission reports on implementation and see, for example, the Fourth Implementation Report on Programmes of Measures (2015) available at http://ec.europa.eu/environment/water/waterframework/impl reports.htm\#fourth Accessed ${ }^{* * * *}$.

${ }^{59}$ European Environment Agency 9/2012 European Waters - current status and future challenges synthesis (2012) s.2.2.1 The ecological status of water and subsequently see COM (2015) 120 The Water Framework Directive and the Floods Directive: Actions towards the 'good status' of EU water and to reduce flood risks, which reports' under section 3.2, Using too much water: over-abstraction, that excessive abstraction significantly affects $10 \%$ of surface water bodies and $20 \%$ of groundwater bodies.

${ }^{60}$ House of Lords, European Union Committee, An Indispensable Resource: EU Freshwater Policy. 33rd Report of Session 2010-12 (HL Paper 296) published 2 May 2012.

${ }^{61}$ On national water resource planning see W. Howarth, Planning for Water Security (2012) Journal of Planning and Environment Law 357
} 
status' objective of the Directive cannot meaningfully be pursued without effective action on water resource availability." 62

The relationships between water quality, water quantity and good status under the WFD were also a recurring theme in a series of reports published by the European Environment Agency in 2012 to inform the Blueprint. ${ }^{63}$ It was noted that,

" . . . . The WFD is the first piece of European environmental legislation that addresses hydromorphological pressures and impacts on water bodies. It requires action in those cases where the hydromorphological pressures affect the ecological status, interfering with the ability to achieve the WFD objectives. If the morphology is degraded or the water flow is markedly changed, a water body with good water quality will not achieve its full potential as a habitat for wildlife. . ... Water resource management needs to be an integrated part of the RBMP. ${ }^{64}$

To address this shortcoming, it was suggested,

"One way of conceiving problems of water quantity is the concept of a 'flow regime', which describes the volume and seasonal rhythm of water flow in a water body. The 'ecological flow' is defined as the amount of water required for the aquatic ecosystem to continue to thrive and provide the services we rely upon. Ecological flow needs to be part of the overall good status assessment. . . . Altered flow regimes can have a high impact on the functionality of the ecosystem .... More conceptual work is therefore needed to develop the concept of 'ecological flow' in the good status assessment."65

Hence the overall submission of the Agency was that

"the ... definition of good status needs to be specified in greater detail. Good status should therefore include the concept of 'ecological flows', a term that describes the volume of water required for an aquatic ecosystem to continue to thrive and provide the services we rely on."66

Given the gravity of the observations and recommendations from the European Environment Agency reports, it was not surprising that the suggestions on ecological flow were fully endorsed in the Commission's Water Blueprint.

\footnotetext{
${ }^{62}$ Para 68 HoL Report Ibid.

${ }^{63}$ See particularly, the European Environment Agency's 'thematic assessments': 1 Towards efficient use of water resources in Europe (Report 1/2012, 2012); 2 European waters - assessment of status and pressures (Report 8/2012); 3 Water resources in Europe in the context of vulnerability (Report 11/2012) and the Synthesis report: Europe's water resources: Current Status and Future Challenges (Report 9/2012) available at http://www.eea.europa.eu/publications\#c14=\&c12=\&c7=en \&c11=5\&b start=0. Accessed ${ }^{* \star * *}$. ${ }^{64}$ EEA 8/2012 p.10

${ }^{65}$ EEA No 9/ 2012 p.20 citing Sánchez and Schmidt 2012, ${ }^{* * *}$ see below and Bunn, S.E. and Arthington, A.H., 2002. 'Basic Principles and Ecological Consequences of Altered Flow Regimes for Aquatic Biodiversity', Environmental Management 30 (4): 492-507. doi:10.1007/s00267-002-2737-0. Accessed ${ }^{* * * *}$.

${ }^{66}$ EEA 9/2012 Summary
} 
"To address the issue of over-allocation [of water for abstraction], there is a need in many EU river basins to put quantitative water management on a much more solid foundation: namely the identification of the ecological flow, i.e. the amount of water required for the aquatic ecosystem to continue to thrive and provide the services we rely upon. Fundamental to this is the recognition that water quality and quantity are intimately related within the concept of 'good status'. However, there is no EU definition of ecological flow, nor a common understanding of how it should be calculated, even though these are preconditions for its consistent application. To address this gap, the Commission proposes developing a guidance document in the framework of the WFD Common Implementation Strategy, using its open and participatory process." 67

\section{The Ecological Science on Water Flow}

The European Commission's Water Blueprint usefully drew attention to lack of a definition or common understanding of the concept of 'ecological flow'. This prompted a significant discussion on how a concept from ecological science could be translated into the kind of norm that would fit within guidance under the Common Implementation Strategy (hereafter CIS) for the WFD. ${ }^{68}$

The clear findings, from an extensive body of ecological scientific literature, showed a fairly wide consensus that water flow regimes play a primary role in determining the structure and functioning of aquatic ecosystems. ${ }^{69}$ Broadly, the evidence supported the view that natural flow regimes display variability at a range of time scales, including seasonal, and inter-annual, and native aquatic and riparian biota are adapted to this variability. For this reason, the magnitude, frequency, duration, timing and rate of change of the natural flow regime are generally agreed to be the key elements central to sustaining and conserving native species and ecological integrity. It is important, therefore, to appreciate that 'natural flow' is about variability of flow, not simply the minimum flow for any particular period of the year.

\footnotetext{
${ }^{67}$ The EU Blueprint, COM(2012) 673 final A Blueprint to Safeguard Europe's Water Resources p.6 ${ }^{68}$ See Sánchez Navarro, R. and Schmidt, G., 2012, 'Environmental Flows as a Tool to Achieve the WFD Objectives: Discussion Paper', Draft 2.0 of 11 June 2012, European Commission, Typsa and Intecsa-Inarsa and C. Theodoropoulos and N. Skoulikidis, Environmental flows: the European approach through the Water Framework Directive 2000/60/EC, Proceedings of the $10^{\text {th }}$ International Congress of the Hellenic Geographical Society, available at https://www.researchgate.net/publication/267574916 Environmental flows the European approach through the Water Framework Directive 200060EC. Accessed ${ }^{* * * *}$.

${ }^{69}$ See particularly Poff, N.L., J.D. Allan, M.B. Bain, J.R. Karr, B. Prestegaard K.L., Richter, R.D., Sparks, R.E.. Stromberg J.C., 1997. "The natural flow regime: a new paradigm for riverine conservation and restoration”. BioScience 47:769-784 and Poff, N.L. and Zimmerman J. K., 2010. Ecological responses to altered flow regimes: a literature review to inform the science and management of environmental flows. Freshwater Biology (2010) 55, 194-205.
} 
In support of what has come to be termed the 'natural flow paradigm', the importance of this has been seen to be attributable to four key factors:

1. The hydrological regime is an important determinant of physical habitat, which in turn determines the biotic composition and life history strategies;

2. Aquatic species have evolved in direct response to the natural hydrological regime;

3. Maintaining natural patterns of longitudinal and lateral connectivity is essential for the viability of populations of species; and

4. The success of the invasion of exotic and introduced species is facilitated by the alteration of hydrological regimes. ${ }^{70}$

Despite a high degree of scientific consensus, translating the natural flow paradigm into a regulatory requirement or normative guidance is far from straightforward.

There is little room for argument about the adverse ecological impacts arising from quantitative stresses upon European waters:

"In many locations, water demand often exceeds availability, and the need for adequate water supplies to service vulnerable ecosystems is often neglected. Over-abstraction is causing low river flows, lowered groundwater levels and the drying-up of wetlands, with detrimental impacts on freshwater ecosystems."71

However, establishing a general scientific relationship between natural flow and ecological integrity and seeking to impose natural flows in a particular water as a normative requirement, are categorically different kinds of exercise. Not least, this is because an unsatisfactory ecological status in any particular watercourse may be attributable to a range of other factors apart from unsatisfactory flow. Imposing natural flow as a mandatory requirement seems hard to justify where it cannot be shown that unsatisfactory flow is the reason for a failure to reach good ecological status.

\section{The Common Implementation Strategy Guidance}

The Commission's preferred mechanism to address the problem of identifying securing ecological flows was through guidance under the CIS, rather than through any substantive change to the WFD. On this it should be noted that, as compared with previous EU environmental legislation, the implementation of the WFD is distinctive in respect of the role of guidance on its practical interpretation and application. In part this may reflect that aspects of the Directive are of considerable technicality and it is important that shared understandings of these are reached between competent authorities in different member states. In part also, guidance

\footnotetext{
${ }^{70}$ Bunn, S E. and A.H. Arthington. 2002. "Basic principles and ecological consequences of altered flow regimes for aquatic biodiversity”. Environmental Management 30:492-507.

${ }^{71}$ European Environment Agency 2010. The European Environment State and Outlook: Water resources: quantity and flows. (Report 1/2010) EEA, Copenhagen, Denmark available at, http://www.eea.europa.eu/soer/europe/water-resources-quantity-and-flows. Accessed ${ }^{* \star * *}$.
} 
can be promulgated with a lesser degree of formality than is needed for amendment of the Directive, though this may give rise to concerns about democratic accountability. ${ }^{72}$ For the purpose of providing this guidance, the WFD CIS was established at EU level, involving working groups of experts and stakeholders from member states producing a series of documents on key aspects of implementation of the Directive. These CIS guidance documents are expressly stated to be 'nonlegally binding', but are important in establishing a coherent application of key elements of the Directive across the member states. ${ }^{73}$

The specific response for the call for guidance on ecological flows is CIS Guidance Note 31: Ecological Flows in the Implementation of the Water Framework Directive. ${ }^{74}$ CIS 31 notes the Water Blueprint finding that water quality and quantity are intimately related within the concept of good status and that widespread overabstraction needs to be addressed to allow the amount of water needed for the wellbeing of aquatic ecosystems. For that purpose, the guidance seeks to provide the advice and assistance on water flows (alternatively termed 'ecological flows', 'environmental flows' or 'Eflows') that is needed to inform the second cycle of river basin planning, leading to the adoption of new plans by December $2015 .{ }^{75}$ Hence, member states are expected to undertake a "gradual and incremental consideration of the recommendations" before the adoption of new river basin management plans and in subsequent planning steps such as the review of monitoring programmes, making operational their programmes of measures by December 2018 and in the implementation throughout the second cycle of planning. ${ }^{76}$

For the purposes of CIS 31, "ecological flow" is given a wide definition as "a hydrological regime consistent with the achievement of the environmental objectives of the WFD in natural surface water bodies". Whilst this is inherently related to the ecological requirements for good status of surface waters, it may also be related to artificial or heavily modified water bodies or to bodies that qualify for various kinds of exemption from the good status requirement, as previously mentioned. Hence

\footnotetext{
${ }^{72}$ See M. Lee. Law and Governance of Water Protection Policy, p.27 in J. Scott ed. Environmental Protection: European Law and Governance (2009) for a useful discussion of the accountability concerns.

${ }^{73}$ See European Commission, Water Framework Directive Guidance Documents at http://ec.europa.eu/environment/water/water-framework/facts_figures/guidance_docs_en.htm Note particularly Guidance Document No.1 Economics and the environment - The implementation challenge of the Water Framework Directive (2003) which sets out some general principles concerning the role of guidance in the implementation of the Directive. See also the further national guidance provided by the UK Technical Advisory Group (UKTAG) for Water Framework Directive on UTAG website www.wfduk.org. Accessed ${ }^{* \star * *}$.

${ }^{74}$ WFD Common Implementation Strategy, Guidance Document 31 (2015) Ecological Flows in the Implementation of the Water Framework Directive available at:

https://circabc.europa.eu/sd/a/4063d635-957b-4b6f-bfd4b51b0acb2570/Guidance\%20No\%2031\%20\%20Ecological\%20flows\%20\%28final\%20version\%29.pdf. Accessed ${ }^{* * * *}$. Hereafter CIS 31 ${ }^{75}$ For the new River Basin Management Plans for the UK see https://www.gov.uk/government/collections/river-basin-management-plans-2015. Accessed ${ }^{* * * *}$. ${ }^{76}$ CIS 31 pg.9
} 
where these waters are concerned, the corresponding flow regime will need to take into account technical feasibility and socio-economic impacts on the relevant use that would be affected by the implementation of an ecological flow regime. ${ }^{77}$

Whilst the CIS 31 seeks to promote a common understanding of ecological flows at a conceptual level, it also recognises that there will be a significant degree of discretion in the practices adopted by member states that are presently at quite different levels of development in respect of flow regulation. Hence, in 2012, a study of the assessment of the implementation of Eflows in RBMPs found that 88 river basin districts $(47 \%)$ either had already implemented minimum ecological flows or planned to implement these in the framework of a programme of measures, while another 69 (34\%) showed no explicit intention in this regard and in a further 29 $(16 \%)$ there was insufficient information to evaluate implementation. However, as has been noted, minimum flow is only one aspect of the variability needed for natural ecological flow, and significant variations in approach to quantitative water management were evident in different member states. ${ }^{78}$

Key recommendations propounded by the CIS 31 are that national frameworks should include:

- a conceptual definition of ecological flows with a clear reference to both flow quantity and dynamics and to their consistency with the environmental objectives required under the WFD;

- ecological flows as a binding requirement where relevant:

o to all water uses (in particular abstraction, impoundment, flow regulation) in their different characteristics (surface and groundwater, reversible and irreversible, periodic and permanent);

0 in the strategic planning for development of impacting uses

0 in the delivery of new permits

0 in the review of existing water rights

- conditions for exemptions to this requirement should be consistent with related exemptions in the WFD ( under Article 4 (4) to (7) WFD).

- clear responsibility for validating the definition of ecological flows and the inspection of their achievement

- deterrent penal provisions when regulatory requirements are breached. ${ }^{79}$

As regards implementation, CIS 31 is emphatic on the need for programmes of measures to ensure the protection of ecological flows and their restoration in order to meet the environmental objectives of the Directive. As part of the basic measures,

\footnotetext{
${ }_{77}$ lbid. pg.20.

${ }^{78}$ Benítez, C. and Schmidt, G. 2012. Analysis of the implementation of Environmental Flows in the wider context of the river basin management plans European Commission, Intecsa Inarsa, available at

http://ec.europa.eu/environment/archives/water/implrep2007/pdf/Water\%20abstraction\%20and\%20us e\%20-\%20Eflows.pdf. Accessed ${ }^{* * *}$.

${ }^{79} \mathrm{CIS} 31$ p.24
} 
controls on surface and groundwater abstractions, impoundments and other activities impacting on hydromorphology should form a strong basis to protect and restore ecological flows, through the authorization process and regular review of permits. In addition, it is suggested that supplementary measures may be needed such as the combination of hydrological measures (ensuring the maintenance of ecological flows by all abstractions and regulation) and morphological measures (improving the aquatic habitats in order to make them less vulnerable to flow impairments) may be the most cost-effective approach. ${ }^{80}$

\section{UK Provisions and Practice on Water Flows}

Although the CIS guidance may be seen as a consolidation of scientific and normative understandings of ecological flow requirements, the practical significance of the guidance is best demonstrated by investigating its impact upon national practice within member states. To offer some insights into this, the final part of the discussion reviews some of the difficulties in of translating ecological flows requirements into national practice in the UK, and England in particular.

\section{A National Practice on Flow Regulation}

By international comparisons, the UK has shown a fairly longstanding recognition of the importance of water flows. Statutory provisions for 'compensation' flows of water from reservoirs were commonly made in private or local legislation authorising dams and other hydrological works dating back to the $19^{\text {th }}$ century. ${ }^{81}$ More generally, national legislation has provided for the concept of 'minimum acceptable flow' as a longstanding requirement for water resource planning. For this purpose, the Secretary of State is empowered to make a determination of this level of flow for particular waters on the basis of proposals from the Environment Agency. ${ }^{82}$ The purpose of minimum acceptable flows seems to be primarily connected with ensuring public health needs and the requirements of existing water users for various purposes including agriculture, industry and water supply (with no explicit references to ecological flow concerns). ${ }^{83}$ Remarkably however, it appears that, in practice, no actual determination of minimum acceptable flow have ever been made, perhaps because of the difficulty of ascertaining what flow is needed for the different

\footnotetext{
${ }^{80} \mathrm{CIS} 31$ p.62

${ }^{81}$ Gustard et al, A Study of Compensation Flows in the UK, Institute of Hydrology Report 99, Wallingford UK 1987 cited by Dunbar, M.J., Acreman, M., and Kirk, S. 2004. Environmental flow setting in England and Wales: Strategies for managing abstraction in catchments. Journal of Water and Environmental Management 18: 5-10, and now see A. Gustard, A. Bullock and J. M. Dixon, Low flow estimation in the United Kingdom, 1992 Institute of Hydrology Report No.108 available at http://nora.nerc.ac.uk/6050/1/IH 108.pdf, accessed ${ }^{* * *}$ and see Reid, CT, Pillai, A and Black, AR 2005, 'The emergence of environmental concerns: hydroelectric schemes in Scotland' Journal of Environmental Law, vol 17, no. 3, pp. 361-382

${ }^{82}$ Now see s.21 Water Resources Act 1991, replacing s. 19 Water Resources Act 1963, with detailed provisions under Schedule $V$ to the 1991 Act.

${ }^{83}$ Ibid s.21(2)(c) 1991 Act.
} 
purposes for which they are required. Despite this, the concept of minimum acceptable flow remains important because licences for abstraction and impoundment, as the key mechanisms for water resources management, require prior consideration to be given to the same considerations that would be relevant in determining the minimum acceptable flow. ${ }^{84}$

The inability or unwillingness to determine minimum acceptable flows for watercourses perhaps reflects the scientific and technical difficulties in translating the water flow concept into a workable mechanism for practical water resources management. Moreover, the national idea of a minimum flow is relatively limited by comparison to the 'ecological flow' required for WFD purposes, since, as has been seen, this is concerned with all aspects of natural flow, at low, medium and high levels. ${ }^{85}$

\section{B National Guidance on Managing Abstraction}

The need to give national effect to WFD requirements for ecological flow has required a significantly more sophisticated national approach towards water resources management. The new approach has been based on proposals from the United Kingdom Technical Advisory Group on the Water Framework Directive (hereafter UKTAG) ${ }^{86}$ The regime that has been adopted involves the application of national 'flow standards' which are used to identify the hydrological status of surface waters by calculating the difference between the natural flow regime and the actual measured flow of particular waters. Natural flow is determined as the flow that would occur in the absence of artificial influences (such as abstractions, discharges and flow regulation). If a watercourse shows less than $5 \%$ difference from its natural flow, for either abstraction or discharge, it is deemed to meet the standard for high ecological status under the Directive. However, rivers are also recognised to vary in sensitivity, as measured by the difference in flow that would be needed to have an adverse effect upon ecology, and each river is assigned to a 'type' classification which reflects that sensitivity. Hence, to meet good ecological status the amount of difference to natural flow that is allowed will depend on the time of year, the type of catchment and the flow. For example, in a clay catchment at low flows, natural flow

\footnotetext{
${ }^{84}$ Ibid. S.40(2) 1991 Act.

${ }^{85}$ Generally on the difficulties of determining flows, see Dunbar, M.J., Acreman, M, Defining Environmental River Flow Requirements - A Review August 2016 - Hydrology and Earth System Sciences https://www.researchgate.net/publication/26435294 Defining Environmental River Flow Requireme nts - A Review. Accessed ${ }^{\star \star \star \star}$.

${ }^{86}$ UKTAG is a partnership of the UK environment and conservation agencies which was set up to provide coordinated advice on the the science and technical aspects of the WFD by the UK-wide WFD policy group consisting of UK government administrations. See http://www.wfduk.org/aboutuktag-and-jagdag. Accessed ${ }^{* * * *}$. UKTAG, UK Environmental Standards and Conditions (Phase 2) Final (SR1 - 2007) March 2008 p.54-55 at http://www.wfduk.org/sites/default/files/Media/Environmental\%20standards/Environmental\%20standar ds\%20phase\%202 Final 110309.pdf. Accessed ${ }^{* * * *}$.
} 
may be reduced by up to $15 \%$ (April to March) whereas in salmonid spawning and nursery areas the permissible reduction is only $10 \%$. For stillwaters, a similar approach has been adopted. ${ }^{87}$

\section{Environment Agency Management of Water Abstraction}

In practice, the assessment of water flows and the availability of water for abstraction is undertaken in England by the Environment Agency which, since 2001, has adopted a Catchment Abstraction Management Strategy (hereafter CAMS) approach towards these assessments, as a part of River Basin Management Planning under the WFD. Hence, CAMS are seen to be 'supporting the objectives' of the WFD at catchment level by: providing a resource assessment of rivers, lakes, reservoirs, estuaries and groundwater; identifying water bodies that are failing, or are at risk of failing to meet good ecological status due to water resource pressure; preventing deterioration of water body status due to new abstractions; and providing results which feed into River Basin Management Plans. This involves the use of environmental flow indicators, aligned with good status requirements for relevant waters, to ensure that abstractions do not contribute to a deterioration in ecological status. Hence, abstraction licensing is regarded as a central mechanism under basic measures, within the programmes of measures for achieving environmental objectives under the Directive. ${ }^{88}$

\section{Environmental Flow Indicators}

As has been noted, the critically important environmental indicators, which serve as flow standards within the Environment Agency's CAMS approach to abstraction licensing, are based upon proposals from UKTAG and issued as guidance from the Department for Environment, Food and Rural Affairs (hereafter DEFRA) on the implementation of the WFD. As a precursor to the establishment of the second cycle of river basin management plans (required by December 2015) DEFRA published new and updated environmental standards to protect the water environment, to be used in the preparation of these plans. ${ }^{89}$ These standards are to be read alongside

\footnotetext{
${ }^{87}$ From DEFRA Managing Abstraction and the Water Environment 2013 p.6 available at https://consult.defra.gov.uk/water/abstractionreform/supporting documents/abstractreformconsultmanage20131217.pdf. Accessed ${ }^{* * * *}$. ${ }^{88}$ Environment Agency, Managing Water Abstraction 2013 available at https://www.gov.uk/government/uploads/system/uploads/attachment data/file/297309/LIT $489220 f 7$

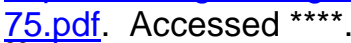

${ }^{89}$ DEFRA and Welsh Government, Water Framework Directive implementation in England and Wales: new and updated standards to protect the water environment May 2014, see particularly Ch. 6 on water level flow standards, available at https://www.gov.uk/government/uploads/system/uploads/attachment data/file/307788/river-basinplanning-standards.pdf. Accessed ${ }^{* * *}$.
} 
the more general updated Guidance to the Environment Agency and Natural Resources Wales on River Basin Management Planning $2014 .^{90}$

Despite the recent prominence given to ecological flows under the CIS guidance, the updated national guidance on environmental standards for river flows advises that there should be no revision of existing standards for river flows used to assess the risk to ecological quality posed by abstractions. The basis for retaining the existing standards was a review undertaken by UKTAG which found uncertainty in the precise relationship between flow changes and good ecological quality. For this reason, it was recommended that, in a river in which the flow standards for good status are breached, supporting evidence of adverse ecological impacts is needed to have high confidence that the river is in a worse than good ecological status. ${ }^{91}$

The UKTAG Review ${ }^{92}$ of environmental standards, which provided the basis for the recent DEFRA advice, looked at scientific developments since its previous recommendations (in $2007^{93}$ ) on the percentage of the natural flow that may be abstracted without a significant risk of damage to the ecology of rivers at different states of flow. The Review advised that there was no quantitative information that could be used to refine standards for flows. The Review was particularly revealing in drawing attention to lack of any clear relationship between flow levels and scores on biological indexes that are designed to be sensitive to river flows. As the discussion in the Review concluded, "requiring costly action is not appropriate for waters classified as moderate status on the basis of river flows unless there is corroborating evidence of ecological damage". 94 These observations are significant because they seem to suggest that, as a matter of science, the relationship between ecological quality and water flow is not so closely correlated as may have been supposed or that there may be factors other than flow which have at least as significant an effect upon ecological quality. As water flow has been characterised as a 'contingent' legal requirement for ecological status under the WFD, the scientific evidence informing UK national practice seems further to illustrate the 'contingent' character of this relationship: unsatisfactory water flow may not always result in unsatisfactory ecological status and "corroboration" is needed to justify action in particular cases. Either way, the relationship between these is not simple and incurring expense to

\footnotetext{
${ }^{90}$ DEFRA and WG, River Basin Planning Guidance 2014 available at https://www.gov.uk/government/uploads/system/uploads/attachment data/file/339471/river-basinguidance-final.pdf. Accessed ${ }^{* \star \star *}$.

${ }^{91}$ Ibid para.6.1.4

92 UKTAG, Updated Recommendations on Environmental Standards River Basin Management (2015-

21) Final Report November 2013 (Minor amendments January 2014), see particularly Ch,5 on River

Flows, available at

http://www.wfduk.org/sites/default/files/Media/Environmental\%20standards/UKTAG\%20Environmenta \%20Standards\%20Phase\%203\%20Final\%20Report\%2004112013.pdf. Accessed ${ }^{* * * *}$.

${ }^{93}$ See ref at ${ }^{* * *}$ above.

94 Ibid (UTAG 2013) p.59.
} 
improve water flow may not be justified unless it can be shown that this is the reason for unsatisfactory ecological status. ${ }^{95}$

\section{E Abstraction Licensing Reform}

Apart from the difficulties in showing a clear relationship between ecological status and water flow, the assumption behind the foregoing discussion is that adequate legal powers exist in national law to address situations where excessive abstraction threatens or causes a deterioration in ecological status. In the UK, a key part of the programme of measures needed to secure the environmental objectives of the WFD is the abstraction licensing system. Historically, this is founded upon the need to manage water resources, primarily for water supply purposes, which prompts the question whether this system is sufficiently flexible to provide an adequate response to actual or anticipated ecological flow needs. On this, it has become apparent over the last few years that the national abstraction licensing regime is in need of major reform to fulfil the needs of the Directive.

Difficulties with the national abstraction licensing system arise for largely historical reasons, in that certain major abstractions, particularly by water undertakers, have remained exempt from licensing requirements. As a consequence, these abstractors are able to take unlimited amounts of water without regard to the environmental impact. Moreover, licences can only be modified or withdrawn where compensation is paid to the licence holder. As a mechanism for effective national management of water resources, therefore, the abstraction licensing system has serious inadequacies. These shortcomings are doubly apparent where the system serves as a principal mechanism in the programme of measures for securing the environmental objectives under the WFD.

The Water Act 2003 sought to amend water resources law, to secure implementation of the WFD, by ending most exemptions from the abstraction licensing requirements, subject to secondary implementing regulations to facilitate this. However, consultation on the implementation of this in 2009 was found to raise "complex issues" which have prompted further rounds of consultation in 2013 and $2016^{96}$ which now raise the prospect of reforms not being implemented until the early $2020 \mathrm{~s}$. The timescales here speak for themselves. Belatedly, the 2003 Act authorised the revocation of certain licences without compensation where this is necessary to

\footnotetext{
${ }^{95}$ See also, Mainstone, C.P. 2010. An Evidence Base for Setting Flow Targets To Protect River Habitat. Natural England Research Reports, Number 035. Natural England, Sheffield. Available at http://publications.naturalengland.org.uk/publication/9025

${ }^{96}$ See DEFRA Consultation Doc 2016 Changes to water abstraction licensing exemptions https://consult.defra.gov.uk/water/water-abstraction-licensingexemptions/supporting documents/Consultation\%20Document\%20\%20New\%20Authorisations.pdf Accessed $^{* * * *}$. This source also provides information on the 2009 and 2013 consultations.
} 
prevent 'serious damage' to the environment. ${ }^{97}$ More recently the Water Act 2014 has removed the need for statutory compensation to be paid to water undertakers where abstraction licences are revoked or modified to restore sustainable levels of abstraction. ${ }^{98}$ However, the bigger problem of an inadequate abstraction licensing system has remained unaddressed.

Implicitly acknowledging that the exemptions from licensing requirements are incompatible with the implementation of the Directive, the 2016 consultation on Changes to Water Abstraction Licensing Exemptions proposes that there should be a two stage approach "to meet WFD requirements of ending the exemptions". The first stage is to bring exempt abstractors into the licensing system and made subject to the RBMP to meet the WFD objectives. ${ }^{99}$ Secondly, it is proposed that environmental constraints should be applied to protect the environment at low flows or drought conditions by the imposition of a 'hands off flow' condition (allowing the regulator to stop abstraction when flows reach a specified threshold) in new authorisations to enable abstraction to be brought within sustainable limits. ${ }^{100}$ "To be compliant with the overall approach required by the WFD" (again, conceding present implementation shortcomings) the Consultation Document anticipates that licences will be subject to the minimum protection standards and consistent with the minimum acceptable flow identified as part of the Catchment Abstraction Management Strategies (CAMS) process. ${ }^{101}$

Certainly, the forthcoming removal of exemptions from the abstraction licencing system will enable all abstractions to be managed in a more consistent manner than is currently possible, but the seemingly interminable exercise of addressing this problem gives the impression of 'too little, too late'. The national experience reflects a painfully slow realisation that a preoccupation with minimum, rather than natural, flows of water fails to engage with WFD ecological requirements and a tardy appreciation of the legal importance of addressing a legally inadequate abstraction regime.

\section{Conclusions}

The conclusions from this discussion can be stated at three levels: global, EU and national.

\footnotetext{
${ }^{97}$ S.27 Water Act 2003 came into effect in July 2012 and see https://www.gov.uk/government/consultations/the-water-act-2003-withdrawal-of-compensation-on-thegrounds-of-serious-damage on the 2012 consultation concerning withdrawal of compensation on grounds of serious damage under the Water Act 2003. Accessed ${ }^{* * * *}$.

${ }_{98}^{98}$. 57 and 58 Water Act 2014.

99 Para 1042016 Consultation.

${ }_{100}$ Para 1082016 Consultation.

${ }^{101}$ Para 1092016 Consultation.
} 
At a global level, it is apparent that the intuitive attractions of IWRM legislation must be tempered by the complexities and challenges that it raises. Sectoral water legislation has the advantage of practicality, but the disadvantage of failing to engage with the multifaceted interrelationships arising between different kinds of water use. It might be unwise to drawn too broad a conclusion from a relatively narrow a case study. Nevertheless, the relatively small task of interrelating qualitative (pollution control) and quantitative (ecological needs) water laws has been seen to give rise to major, if not completely insuperable, challenges. On a wider view, IWRM takes this challenge a (big) step further in seeking to draw regulatory linkages between the full spectrum of possible water uses. The difficulties become exponential and the prospect of realising IWRM makes it, at best, a long-term aspiration.

At EU level, the discussion has shown that the WFD's claims to have adopted a 'holistic' approach to water regulation are exaggerated. The Directive is primarily a water quality measure, from which some quantitative aspects have emerged, largely as an afterthought. The 'contingent' status of the water quantity in the assessment of surface water quality arises from the failure to identify flow as an explicit environmental objective. This may be because of scientific uncertainties about the relationships between water flow and ecological quality or it may be because the issue was seen as peripheral to the main (water quality) purposes of the Directive. Commendably, however, the WFD has shown the capacity to expand its remit through the CIS and the new guidance on ecological flow which has served to give this masked aspect of ecological water management a valuable new prominence in the future implementation of the Directive.

Nationally, at least within England, some reassurance may be drawn from the major, if belated, rethinking of water flow regulation that is taking place. The failings of an outdated abstraction licencing system have become readily apparent in the face of the need to implement the ecological status requirements of the WFD. On this, the national response has been remarkably dilatory and unreceptive to the difference between securing minimum flows and securing natural flows (as required by the Directive). This is not to say that the national position is any worse than other member states, indeed the national approach in the UK was cited with apparent approval in CIS $31,{ }^{102}$ but the fact remains that an awful lot of water has not flowed under the bridge in the time taken to address these matters.

${ }^{102}$ CIS 31 p.29 refers to the guidance used in England and Wales. 